\title{
Statistical evaluation of mineral water from Valcea County area through quality indices
}

\section{MIHAIELA DRAGHICI ${ }^{1}$, LUISA ROXANA POPESCU ${ }^{1 *}$, NARCIS CLAUDIU SPINU ${ }^{1}$, CATALIN MANEA ${ }^{1}$, GABRIEL VALENTIN SERBAN ${ }^{2}$}

\author{
${ }^{I}$ National Research and Development Institute for Industrial Ecology - ECOIND, Ramnicu Valcea Branch, 182 Stirbei \\ Voda Street, 240588, Romania \\ ${ }^{2}$ National Research and Development Institute for Industrial Ecology-ECOIND, 57-73 Drumul Podu Dambovitei Street, \\ 060652, Bucharest, Romania \\ *Corresponding author: mandoc_lui@yahoo.com
}

$\begin{array}{lll}\text { Received: } & \text { Accepted: } & \text { Published: } \\ \text { 03.06.2021 } & 24.06 .2021 & 25.06 .2021\end{array}$

\begin{abstract}
Significant global consumption of mineral water is fueled by perceived therapeutic and medicinal qualities, cultural habits and taste. In Valcea County are several resorts with such mineral springs, which can have multiple benefits for human health. For this reason, it is important to investigate the level of their pollution with heavy metals. The aim of this study was to detect the level of heavy metals present in the studied mineral waters, to evaluate the analytical results using environmental statistical indices, and to compare the results with the legislation in force.

Thus, mineral water samples were collected from three resorts of Valcea County (Baile Olanesti, Calimanesti-Caciulata and Baile Govora). The analyzed metals ( $\mathrm{Cd}, \mathrm{Cr}, \mathrm{Fe}, \mathrm{Mn}, \mathrm{Ni}, \mathrm{Pb}$ and $\mathrm{Zn}$ ) were determined with ICP-EOS technique and the obtained results were compared to enforce legislation. Statistical analyses were applied and two environmental statistical indices, namely the metal distribution coefficient $(k d)$ and the total environmental risk index (IER) were evaluated.

The calculated values for the total environmental risk index were below 0 (IER $\leq 0$ ), which indicates that none of the studied water samples pose a risk for the environment.

The low values of the distribution coefficient indicate a low ability to bind the metal in particles and therefore, insignificant toxicity. The distribution coefficient calculated for zinc $(1.12 \mathrm{~L} / \mathrm{kg})$ and lead $(0.68$ $L / \mathrm{kg}$ ) in Baile Olanesti indicates a high capacity of the metals to bind in particles, compared to other metals.
\end{abstract}

Keywords: quality indices, mineral waters, metals, risk index, distribution coefficient

\section{INTRODUCTION}

Metals are constituents of the earth's crust and are naturally present in soil and water. At the same time, metals are dangerous for aquatic life, by themselves or by their toxic salts, which show great stability. In general, the toxicity of metals in diluted solutions (hypotonic) is conferred by the cations, the harmfulness of the anions being reduced, but in concentrated solutions, the anions also have a toxic effect [1-3].

The reason why these mineral springs were selected for study was due to their therapeutic benefits on the human body, thus, it is important to evaluate their physical-chemical composition. These mineral waters are used to treat various diseases: digestive diseases, kidney diseases, chronic diseases of the liver and bile ducts, respiratory diseases, metabolic and nutritional diseases, dermatological diseases, allergic diseases, occupational diseases (poisoning with heavy metals: $\mathrm{Pb}, \mathrm{Hg}, \mathrm{As}$ ), endocrine disorders, chronic gynecological diseases, etc. [2]. Most of the mineral springs come from precipitation that infiltrates the earth's crust to great depths, from where they return to the surface, loaded with a certain amount of gases and mineral salts, and in some cases with higher temperatures or even a certain degree of radioactivity. The 
most common salts in mineral water content are chlorine, bicarbonate, sulphide, sulphate and phosphate salts. Among the gases, carbon dioxide, which gives rise to carbonated waters, most often enters the combination. Therefore, all waters having a quantity of salts greater than $0.5 \mathrm{~g} / \mathrm{L}$ are considered mineral springs [3-5].

Romania has a lot of spa resorts recognized on international plan, thermal and mineral springs ranking third place in Europe. In Valcea County there are mineral water springs located in Calimanesti - Caciulata, Baile Olanesti, Ocnele Mari and Baile Govora spa resorts [6-9].

For the present study, we used the quality index to determine the level of water pollution with heavy metals [10-16]. Therefore, the water quality index aims at assessing the quality of water through a single numerical value, calculated based on one system which convert all the individual parameters and their concentrations present in a sample, into a single value. This effective method allows comparing the quality of various water samples based on a single numerical value and not only the parameter values of each sample. Any result of water quality measurements can serve as indicator of water quality [12].

During the last years, various water quality indices have been formulated by some national or international organization and applied for evaluation of water quality in different particular cases $[12,13]$. At global level, more than one index could describe overall water quality of the water body $[12,17]$. The studies $[10,12-14]$ show that a number of countries have begun the process of developing composite indices of water quality to describe the domestic water state.

The aim of this study was to determine the content of metals in the mineral waters collected from Valcea County and to evaluate the results through comparison with maximum admissible values. In addition, the metal distribution coefficient $(\mathrm{kd})$ and the total environmental risk coefficient (IER) were calculated [17].

\section{MATERIALS AND METHODS}

\section{Equipment and method}

The equipment used to perform the experimental studies was calibrated by accredited laboratories. A Perkin Elmer Optima 5300 DV spectrometer was used to determine the metal ions, a Thermo Scientific Orion Star A215 pH meter was used for $\mathrm{pH}$ and conductivity analysis and a Memmert UF 110 oven, Analytical Balance Precisa XB 220A were used for suspensions.

Inductively coupled plasma optical emission spectrometry (ICP-EOS) method was applied for cadmium, chromium, copper, iron, manganese, nickel, lead and zinc determination, gravimetric method for suspended solids and electrochemical method for $\mathrm{pH}$ and conductivity analysis.

The mineral water samples were collected in accordance with in force sampling standards $[18,19]$.

\section{Chemicals and working solution}

For the calibration curves, certified reference material type standard solutions of $\mathrm{Cd}, \mathrm{Cr}, \mathrm{Fe}, \mathrm{Mn}$, $\mathrm{Ni}, \mathrm{Pb}, \mathrm{Zn}, 5 \% \mathrm{HNO}_{3}$ and ultrapure water were used. All reagents were Sigma Aldrich analytical quality.

\section{RESULTS AND DISCUSSION}

In order to evaluate the quality of mineral waters in the resorts of Baile Olanesti, Baile Govora and Calimanesti - Caciulata regarding their pollution with heavy metals. Thus, momentary samples of mineral waters were collected from 14 springs situated in Baile Olanesti resort, seven springs from Calimanesti - Caciulata Resort and 1 spring from Baile Govora resort.

The aim of this study was to determine the content of metals in the mineral waters collected from the selected sample points and to evaluate the obtained results by comparing with the admitted values from the current legislation and by applying the metal distribution coefficient $(\mathrm{kd})$ and the total environmental risk coefficient (IER).

The quality-analyzed indicators for the studied mineral water samples were $\mathrm{pH}$, suspended solids, cadmium, chromium, copper, iron, manganese, nickel, lead and zinc. 
The experimental results were processed in an Excel program in order to establish the degree of contamination with heavy metals of the studied mineral water samples.

\section{Characterization of the studied area}

The samples collected from three resorts located in Valcea County, namely: Baile Olanesti Resort, Calimanesti - Caciulata Resort and Baile Govora Resort are presented in figure 1 [7].

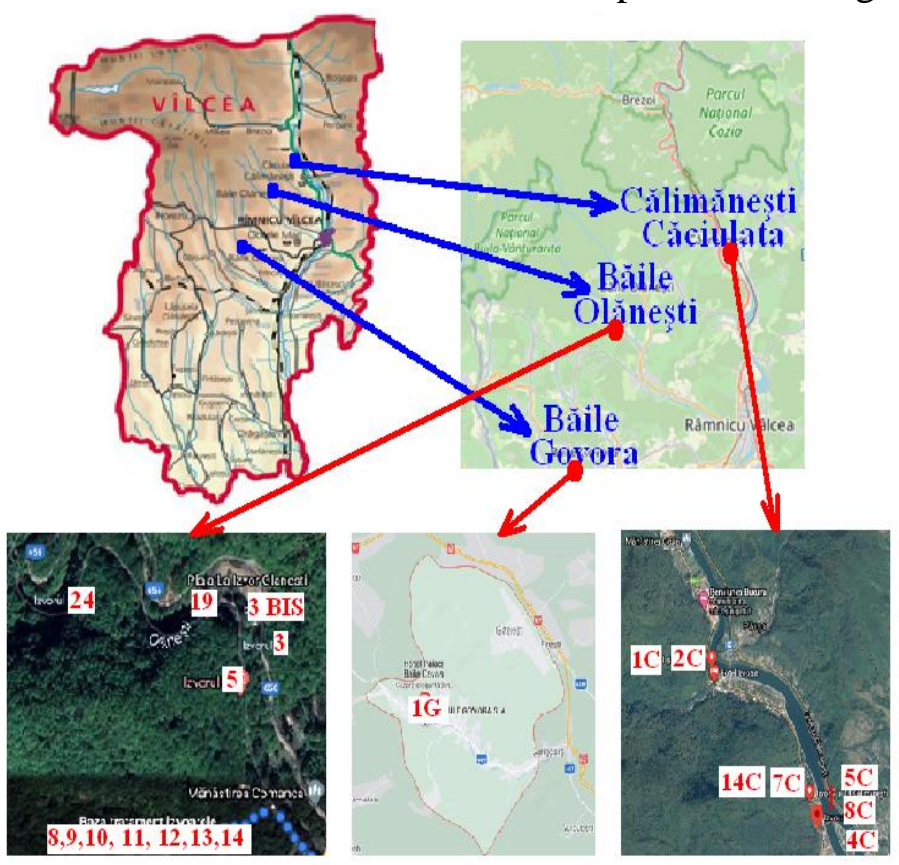

Figure 1. Location of the resorts where the mineral water samples were taken from Valcea County

(Calimanesti - Caciulata, Baile Olanesti and Baile Govora) [6]

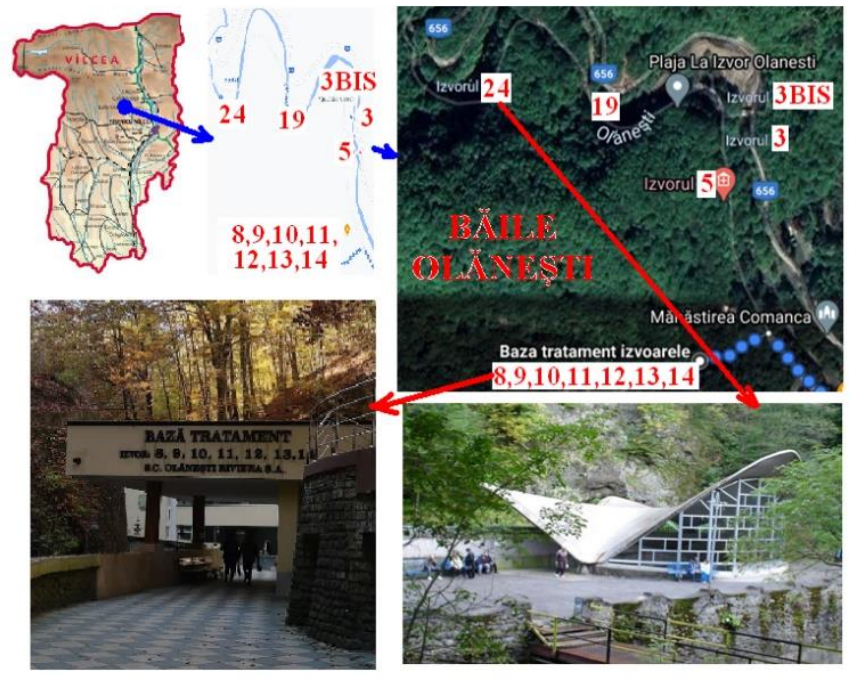

Fig. 2. Map of Baile Olanesti Resort, treatment base of central springs and spring no.24 [6]

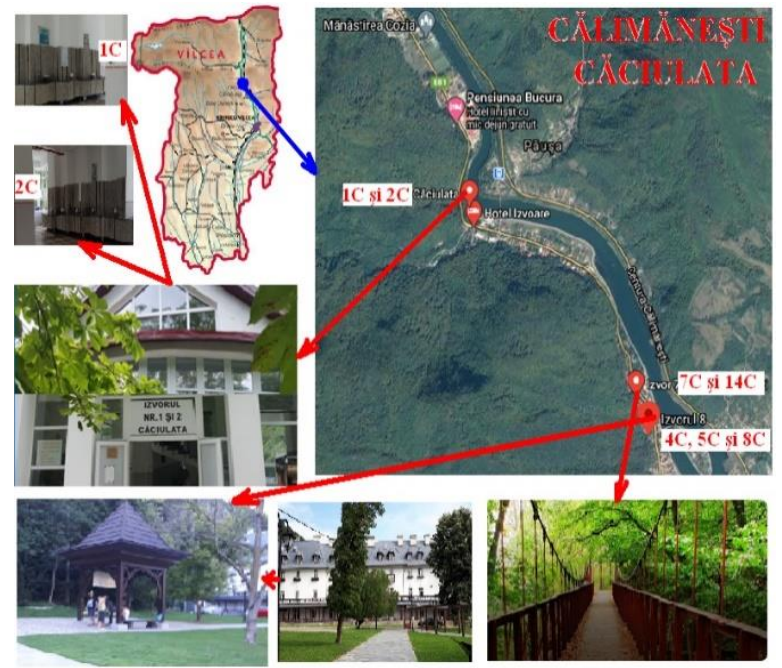

Fig. 3. Map of Calimanesti Resort Caciulata, Central Pavilion of springs $1 \mathrm{C}$ and $2 \mathrm{C}$ from Caciulata, Tower of springs 4C, 5C, 8C [6]

Baile Olanesti Resort is a city located in Valcea County, in an intracoline depression of the Southern Carpathians, surrounded by the Gerea, Folea and Caprareata mountains. Situated at an altitude of $450 \mathrm{~m}$, it is located on both sides of the Olanesti River, a tributary of the Olt River, approximately $18 \mathrm{~km}$ from the city of Ramnicu Valcea county residence. The locality is also nicknamed "Golden Springs", due to the mineral spring's iodinated, brominated, sodium, calcium, 
sulfurous and chlorinated, hypotonic or isotonic (figure 2). Baile Olanesti Resort is one of the few localities in the country that harmoniously combines two natural healing factors: the climatic factor (and local topo climatic), and the hydro-mineral factor consisting of mineral waters [7-9].

Calimanesti-Caciulata resort is located in the central-southern part of Romania, in the northeast of Valcea County, on the right bank of the Olt River, in the Jiblea-Calimanesti sub-Carpathian Depression, at the foot of the Cozia and Capatanii massif in the Southern Carpathians (figure 3). The resort with an altitude of $260-280 \mathrm{~m}$ is situated at $18 \mathrm{~km}$ away from Ramnicu Valcea and 80 km south of Sibiu [7-9].

Baile Govora Resort is considered the second Spa in Europe and world in terms of the number of iodized and brominated waters (figure 4). The resort is also known for the variety and therapeutic nature of its water properties. In addition, Baile Govora Resort is the only resort from the country with mineral waters that have a different chemical composition: iodized, brominated, highly concentrated sulfurous salt waters, hypotonic, sulfurous, bicarbonate, sodium, calcium and magnesium [7-9].

The figures 2 to 4 illustrate the sampling points and the name for the mineral water samples for all three studied villages: Baile Olanesti (sources: 3, 3 bis, 5, 7, 8, 9, 10, 11, 12, 13, 14, 15, 19 and 24), Calimanesti - Caciulata (springs: 1C, 2C, 4C, 5C, 7C, 8 C, 14C) and Govora with spring 1G [6].

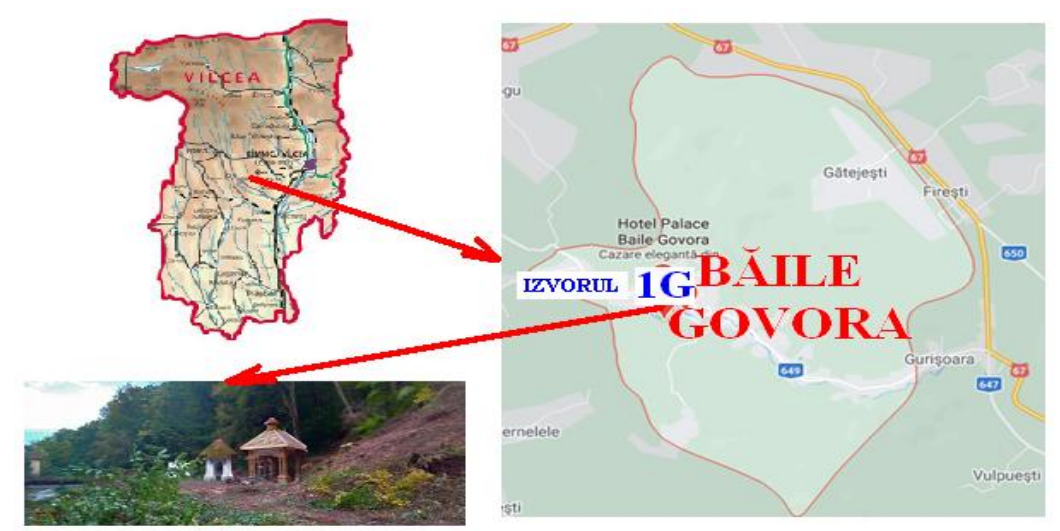

Fig. 4. Map of Baile Govora resort, Mineral waters pavilion [15]

\section{The distribution of the $k d$ coefficient}

The metal partition coefficient $\mathrm{kd}$ is used in various models to describe the distribution of metals between the solid phase and the solution and can be a direct indicator of the solubility of metals in water [12].

The partition coefficient was calculated according to equation (1) and depending on the total concentration of metals $[\mathrm{M}] \mathrm{T}$, the concentration of metals in the dissolved phase [M]D, the concentration of suspended solids TSS. Kd is expressed in L/kg, [M]T and [M]D in $\mu \mathrm{g} / \mathrm{L}$, and TSS in $\mathrm{mg} / \mathrm{L}[17]$.

$$
k d=\frac{([M] T-[M] D) / \mathrm{TSS}}{[M] D} \times 10^{6}
$$

Analysis of both forms of metals present in the mineral water samples was performed to determine the total metals / dissolved metals ratio and correlate the ratio with the $\mathrm{pH}$ value. A high value of $\mathrm{kd}$ indicates an important binding of the metal ions to the suspended particles [12].

In general, at strongly acidic and acidic $\mathrm{pH}$ values, the distribution coefficient values for all investigated metals are small. At neutral $\mathrm{pH}$ values, the binding of metallic elements is more evident, and the release of bound metals to particles, the retention and accumulation of metals in particles takes place under basic conditions of $\mathrm{pH}[17]$. 


\section{Total environmental risk index}

The environmental risk factors for certain hazardous elements $(\mathrm{Cr}, \mathrm{Fe}, \mathrm{Cu}, \mathrm{Cd}, \mathrm{Mn}, \mathrm{Ni}, \mathrm{Pb}$ and $\mathrm{Zn}$ ) were calculated according to (2) equation:

$$
\mathrm{I}_{\mathrm{ER}}=\sum_{i=1}^{n} Q E \operatorname{Eri}^{2}=\frac{A C i}{\mathrm{RCi}}-1 \text {, where: }
$$

IER represent the total environmental risk index of the analyzed sample;

QEri is the index of the environmental risk factor for element $i$, which exceeds the maximum admissible concentration;

Aci is the analytical concentration of the analyzed metal;

$\mathrm{RCi}$ is the maximum admissible value (MAV) allowed in the Romanian legislation, table 1 [20].

Table 1. MAV of the analyzed indicators for mineral water [20]

\begin{tabular}{l|ccl}
\hline \multicolumn{1}{c|}{ Quality indicators } & Measure unit & MAV & \multicolumn{1}{c}{ Observations } \\
\hline $\mathrm{pH}$ & $\mathrm{pH}$ unit & - & according to the natural state of the water \\
Suspended materials & $\mathrm{mg} / \mathrm{L}$ & - & according to the natural state of the water \\
Cadmium & $\mu \mathrm{g} / \mathrm{L}$ & 3 & \\
Chromium & $\mu \mathrm{g} / \mathrm{L}$ & 50 & \\
Copper & $\mu \mathrm{g} / \mathrm{L}$ & 1000 & \\
Total iron & $\mu \mathrm{g} / \mathrm{L}$ & - & according to the natural state of the water \\
Manganese & $\mu \mathrm{g} / \mathrm{L}$ & 500 & \\
Nickel & $\mu \mathrm{g} / \mathrm{L}$ & 20 & \\
Lead & $\mu \mathrm{g} / \mathrm{L}$ & 10 & \\
Zinc & $\mu \mathrm{g} / \mathrm{L}$ & 5000 & \\
\hline
\end{tabular}

The values of the total environmental risk index (IER) are presented in table 2 [17].

Table 2. IER Values and significance

\begin{tabular}{c|c}
\hline $\mathrm{I}_{\mathrm{ER}}$ value & Significance \\
\hline $\mathrm{I}_{\mathrm{ER}} \leq 0$ & without risk \\
$\mathrm{I}_{\mathrm{ER}} \leq 1$ & very low risk \\
$\mathrm{I}_{\mathrm{ER}} \leq 3$ & low risk \\
$\mathrm{I}_{\mathrm{ER}} \leq 5$ & medium risk \\
$\mathrm{I}_{\mathrm{ER}} \leq 10$ & major risk \\
\hline
\end{tabular}

Most of the quality indicators (metals) analyzed from the mineral waters, for all three resorts, registered concentrations lower than the maximum admissible values. The total environmental risk indices calculated for each metal were below the value 0 (IER $\leq 0$ ), which means that the mineral water of these springs does not present a risk for the environment.

\section{The results for mineral water samples from the Baile Olanesti Resort}

Figure 5 illustrates the variations of $\mathrm{kd}$ for each metal studied from all mineral water samples collected from Baile Olanesti Resort. High values of kd indicate a higher ability to bind the metal in particles.

From the graphical representation can be observed that $\mathrm{kd}$ for zinc $(1.12 \mathrm{~L} / \mathrm{Kg})$ and lead $(0.68$ $\mathrm{L} / \mathrm{Kg}$ ) registers higher values than for the other metals. Therefore, zinc and lead have a higher ability to bind to particles compared to other metals.

For cadmium, chromium and nickel, the calculated values of the distribution coefficient varied between 0.0 and $0.22 \mathrm{~L} / \mathrm{Kg}$, which indicates a low particle binding capacity. 
Regarding in force legislation for mineral water quality was observed that the values of studied metals generally were lower than MAVs for most of the mineral water samples collected from Baile Olanesti Resort.

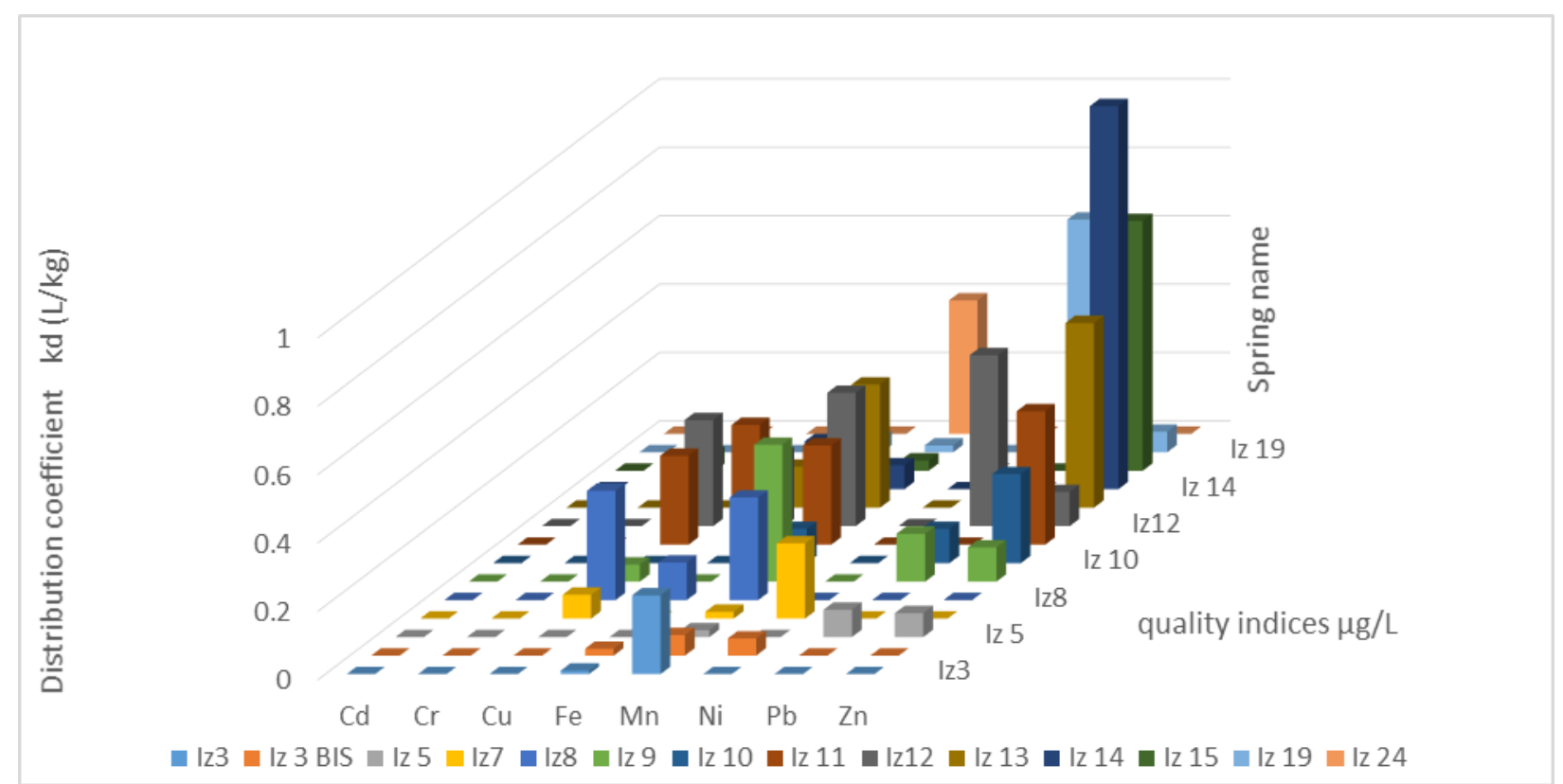

Fig. 5. kd variation of the analyzed metals in each mineral waters from Baile Olanesti Resort

The results for mineral water samples from the Calimanesti - Caciulata Resort

In figure 6, the variations of the distribution coefficient kd are illustrated for each studied metal in all the mineral water samples collected from Calimanesti - Caciulata Resort. The distribution coefficient has values between $0 \mathrm{~L} / \mathrm{Kg}$ (for cadmium, chromium, copper, nickel and lead) and 1.63 $\mathrm{L} / \mathrm{Kg}$ (for manganese at spring 4C). In the same time, all analyzed metals from Calimanesti Caciulata Resort were lower than MAVs.

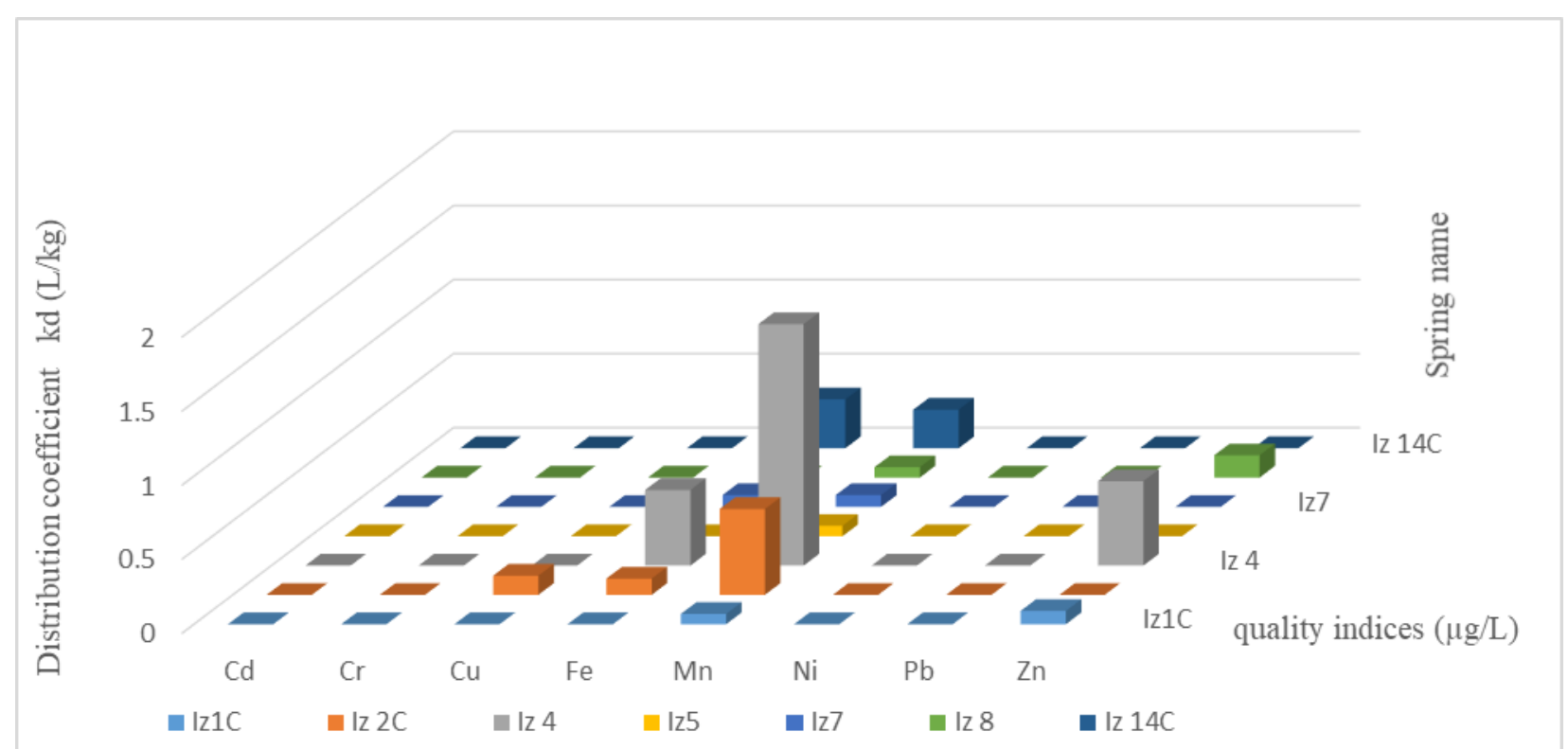

Fig. 6. kd variation of the analyzed metals in each mineral waters from Calimanesti - Caciulata Resort 
The results for mineral water samples from Baile Govora Resort

In $1 \mathrm{G}$ spring from Baile Govora Resort, the kd values are situated in the range 0 to $0.05 \mathrm{~L} / \mathrm{kg}$, indicated that the water sample has an insignificant toxicity (figure 7).

In addition, the values of all analyzed metals were lower than maximum admissible values.

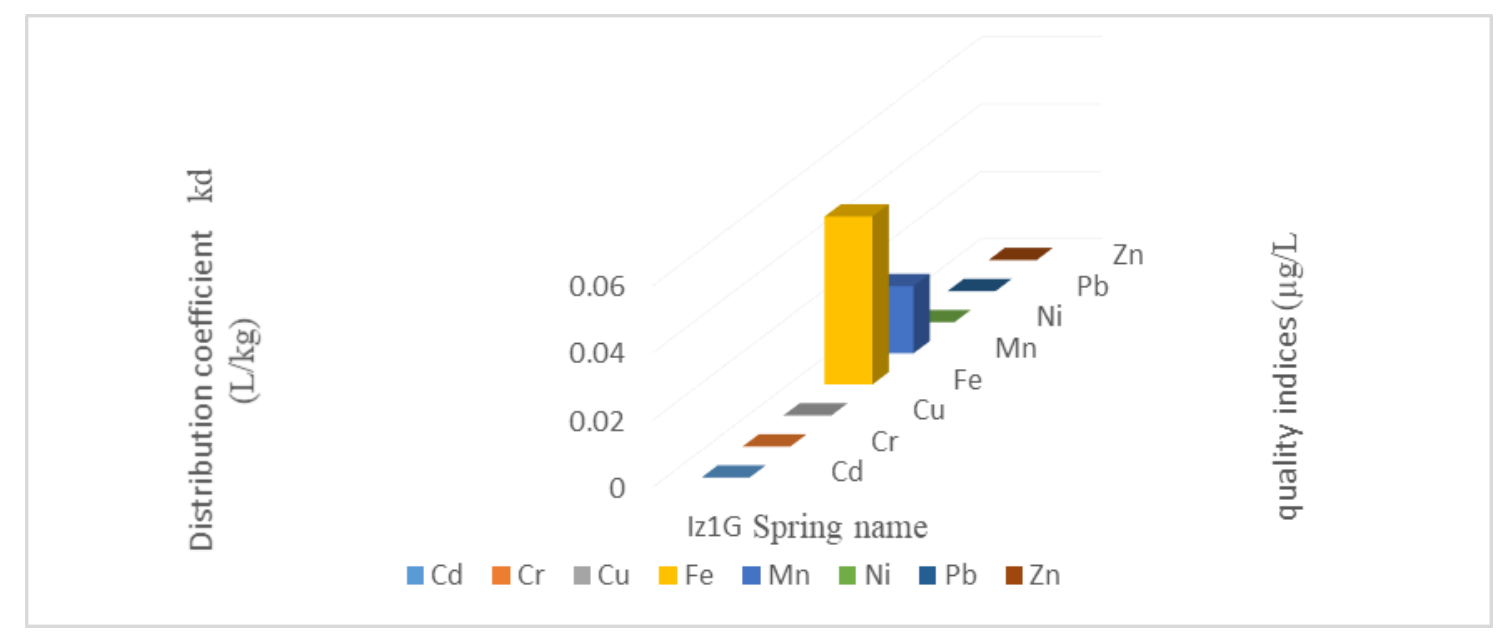

Fig. 7. kd variation of the analyzed metals from Baile Govora Resort

\section{CONCLUSIONS}

The present study aimed to determine the degree of contamination with heavy metals of the mineral water samples using environmental statistical indices.

Due to the chemical composition (iodinated, brominated, sodium, calcium, sulfurous, chlorinated, hypotonic or isotonic) and therapeutic benefits, the mineral springs studied in the Spa resorts from Valcea County are internationally recognized.

In order to assess the quality of mineral waters in Valcea County, in October 2020 twenty-two mineral water samples were collected from springs located in the resorts of Baile Olanesti, Calimanesti Caciulata and Baile Govora.

Cadmium, chromium, copper, iron, manganese, nickel, lead, zinc, $\mathrm{pH}$ and suspensions were analyzed. In order to capitalize the obtained results, the metal distribution coefficient and the total environmental risk index were evaluated.

The values obtained for the total environmental risk indices for each metal were below zero, which indicates that no water samples presented a risk for the environment.

The $\mathrm{pH}$ values of the mineral water samples were situated within the neutral or weakly basic range $(7.3 \div 8.2)$.

Low values of the kd coefficient obtained for each metal indicates a low binding capacity to the particles, therefore the toxicity is insignificant.

In addition was noticed that the values of the analyzed quality indicators were situated below the maximum admissible values according to in force legislation.

\section{ACKNOWLEDGEMENTS}

The work has been funded by National Authority for Scientific Research and Innovation through the Program Nucleu, project code PN 19040101.

\section{REFERENCES}

[1] MARTIN, R., DOWLING, K., J. Asian Earth Sci., 77, 2013, p. 262.

[2] SUDJAROEN, Y., THONGKAO, K., SUWANNAHONG, K., Ann. Trop. Med. Public Health., 10, no. 2, 2017, p. 366.

[3] RUI, Y.K., ZHANG, Y.B., LI, S.L., Asian J. Chem., 25, no. 9, 2013, p. 5103. 
[4] RIVERA-NUNEZ, Z., PAN, Z., DULIENCE, B., BECKER, H., STEENSMA, J., HOBSON, A., GIAMMAR, D.E., IANNOTTI, L.L., Int. J. Environ. Res. Public Health, 28, no. 6, 2018, p. 626.

[5] GHADIMI, F., HAJATI, A., SABZIAN, A., J. Mining Environ., 11, no. 1, 2020, p.171.

[6] https://www.google.com/maps/place. [18.02.2020]

[7] http://www.roturism-info.ro/orase/judetul-valcea/statiuni-balneare/baile-olanesti.html.

[18.02.2020]

[8] https://statiuni-valcea.blogspot.com/2012/01/izvoare-minerale-si-indicatii.html. [18.02.2020]

[9] https://www.balneomedica.ro/izvoare-minerale-in-baile-govora-si-indicatii-terapeutice.

[18.02.2020]

[10] YISA, J., JIMOH, T. O., OYIBO, O. M., Leonardo Journal of Sciences, 21, 2012, p. 33.

[11] YISA J., JIMOH T., Am. J. Appl. Sci., 7, no. 4, 2010, p. 453.

[12] PAUN, I., CRUCERU, L. V., CHIRIAC, F. L., NICULESCU, M., VASILE, G. G., MARIN, N. M., Proceedings of the $19^{\text {th }}$ International Symposium on The Environmental and the Industry, Bucharest, Romania, 13-14 October 2016, p. 395, http://doi.org/10.21698/simi.2016.0055.

[13] VASIlACHE, N., DIACU, E., VASILE, G. G., MODROGAN, C., PAUN, I. C., PIRVU, F., Rom. J. Ecol. Environ. Chem., 2, no. 2, 2020, p. 109.

[14] MOHAMMED, I. U., NDAHI A. K., ADAMU, I. C., Int. J. Multidiscip. Curr. Res., 3, 2015, p. 215.

[15] MATICA, O., Popescu, R.L., Proceedings of the $21^{\text {st }}$ International Symposium on the Environment and the Industry, Bucharest, Romania, 20-21 September 2018, 2, p. 195, http://doi.org/10.21698/simi.2018.fp24

[16] DINU, C., SCUTARIU, R. E., VASILE, G. G., TENEA, A. G., PETRE, J., CRUCERU, L. V., Rom. J. Ecol. Environ. Chem., 2, no. 2, 2020, p. 99.

[17] BIRSAN, E., DIACU, E., Chemical analysis of metals speciation in water bodies anthropically polluted -Ph.D. Thesis, Politehnica University of Bucharest, 2012, in Romanian.

[18] SR EN ISO 5667-1: 2008- Water quality. Sampling. Part 1: General guide for establishing sampling programs and techniques

[19] SR EN ISO 5667-5: 2017- Water quality - Sampling - Part 5: Guide for drinking water sampling from treatment plants and distribution network.

[20]. Government Decision no. 1020 for the approval of the Technical Norms for the exploitation and marketing of natural mineral waters, Romanian Official Monitor no. 854 from 22th September (GD 1020: 2005), 2005.

Citation: Draghici, M., Popescu, L.R., Spinu, N.C., Manea, C., Serban, G.V., Statistical evaluation of mineral water from Valcea County area through quality indices, Rom. J. Ecol. Environ. Chem., 2021, 3, no. 1, pp. 71-78.

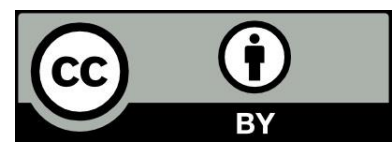

(C) 2021 by the authors. This article is an open access article distributed under the terms and conditions of the Creative Commons Attribution (CC BY) license (http://creativecommons.Org/licenses/by/4.0/). 